\title{
人工臓器高機能化へのチャレンジ 一ハイブリッド型人工肝臓一
}

\author{
戸 辺 成四郎・小林一清・赤池 敏 宏
}

\section{1. はじめに}

不可逆的な㻤器(組織)疾患に対しては, 人工瀻器による 機能代行の他に滕器(組織)移植も有効な手段と考元られ ている。それぞれには一長一短があり，特に移植に関し ては感染症の增大と限られた提供数などの大きな障害が あり,とりわけ我国においては人工葴器に対し大きな期 待が奇せられている。このような動きの中で，高分子を 筆頭とする各種材料は人工䐟器システムを担う最も重要 な素子となっているが，肝䑏，膵橫などの代謝系・内分 泌采闌器はその機能が極めて高度でかつ複雑であるため に, 人工林料に絊胞を組み込んだハイブリッド型人工臟 器の開発が不可欠とされている。ここでは朋臟を例とし てハイブリッド型人工䐵器の設計論における現状および 問題点などについて述べる。

肝臟住, 生体の恒常性維持を司る体内最大の代謝臟器 であり, 種々の血中タンパク質の合成・分泌をはじめ, リポタンパク質に付随する脂質の合成，糖新生，アミ， 酸代謝，ビタミンの活性化，アンモ二ア処理につながる 尿素合成,アルコール・薬物・毒物など外来性異物の解 毒, さらには脺䏢との連携プレーによる血糖値の調節な ど多種多様な代謝機能を有している。この䐟器に肝癌, 肝硬変, 肝炎というような障害が生じて,ひとたび組織 が唚されると代謝調節機能の急激な低下により死に至る 場合も多い。しかし，現在のところ死亡率の高いこれら 肝疾患に対する予防菜や疾患の進展を完全に停止させ得 る治寮薬はない。また，この臓器の有する複雑多岐にわ たる機能を代行し得る生体䐵器あるいは人工材料のみに よる人工肝灆も存在しない。

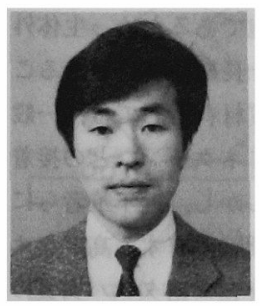

戸辺成四郎氏

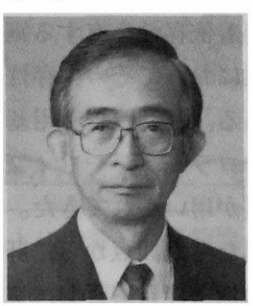

小林 一清氏

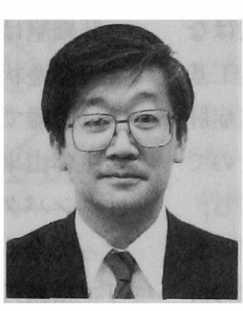

赤池 敏宏氏
近年, 重篤な肝疾患のひとつである胆道閉鎖症の患者 に対し，島根医科大学において我国初の生体部分肝移植 手術が行なわれた。この手術を皮切りに京都大学, 信州 大学と相次ぎ肝葴の一部を切りとって患者に移植する治 療法の臨床応用が行なわれてきた。しかしながら，移植 に対してはシクロスポリンなどをはじめとした優れた免 疫抑制剤が開発されているものの, 依然として拒絶反応 を完全に避けることはできず, また, 薬の副作用として の感染症の増大などにも悩まされている。さらに, 我国 における何よりも大きな問題は, 紛紏している脳死問題 を避けるために，ドナー(提供者)として健康な肉親の腹 を開き，肝荿の一部を取り出す生体部分肝移植が追求さ れているわけであるが,この行為に対する倫理的問題が 残されている。以上のように脳死者からの移植にしろ生 体部分肝移植にしろ, 肝移植の全面的な一般化にはまだ まだ多くの困難が予想される。それ故，我国においては 重篤な肝疾患に対寸る治療法のひとつとして, 人工肝臓 の開発に大きな期待が寄せられているのである。

人工腎臓，人工心臓などのように既に医療に定着した 人工臓器をはじめ、人工血管、人工皮咸、人工関節、人 工骨に至るまで人工的に臟器機能を代替しようとする研 究とその臨床応用が, 近年ますます活発化している。し かし, ごく一部の人工臓器を除き, 完全に臓器機能を代 替するためには，それぞれ幾多の解決すべき問題点を残

The Challenge of Highly Functional Artificial Organs - Hybrid Artificial Liver-

筆者紹介 SEISHIRO TOBE Kanagawa Academy of Science and Technology.

神奈川科学技術アカデミー, 研究貝

KAZUKIYO KOBAYASHI Faculty of Agriculture, Nagoya University.

名古屋大学農学部 助教授, 工学博士

TOSHIHIRO AKAIKE Faculty of Bioscience and Biotechnology, Tokyo Institute of Technology.

東京工業大学生命理工学部 教授, 工学博士

戸辺氏は細胞工学・生化学, 小林氏は榶質高分子化 学, 赤池氏は医用高分子・バイオエレクトロニクス材料 をそれぞれ専門とされている。赤池氏は平成元年度日本 バイオマテリアル学会学会贵を受賞された。

本稿では, 人工肝臓実現へのアプローチについて解説 していたたいた。 
している。とりわけ，複雑多岐にわたる高級な機能を有 する肝臓においては，人工材料のみによる機能代行は不 可能といって良いはどである。このような背景から肝臟 の有する代謝調節機能をまるごと代行してくれるものと して，肝機能の中心を担う肝細胞を人工材料などのマト リックスに組み込んだハイブリッド型人工肝荿の開発一 の期待が生まれた。しかし，肝䑏の補助装䈯として長期 間に招よぶ安定性と代行機能を高度に発現維持するよう なハイブリッド型人工肝臓は未だ開発されていないのが 現状である。

\section{2. ハイブリッド型人工肝朣開発における背景}

現在，臨床的に用いられている人工肝臓と呼ばれるも のは，肝不全などの場合に血中に增加するアンモニアや 急性薬物中毒時の化学物質などを除去(除去療法)するた め，活性岸などの吸着剤を利用しているものである。 Kiley ら”は，肝不全時に急激に增加する血中アンモ二 アを人工腎臓用のセルロース膜を用いた透析により除去 する試みを報告した。また，Yatzidisら ら は急性薬物中 毒や尿毒症の治療法として，ヤシガラ活性炭を用いた体 外灌流システムにより血流灌流を行なった。これらが現 在の人工肝臓の始まりといえる。その後，透析膜や吸着 鼡などの開発により，これらのシステムにさらに改良が 加充られてきた。しかし，これらのシステムは多彩な肝 機能のうち解毒というごく一部の機能を生理的メカニ ズムとは全く異なる原理(物理的吸着)で代行するだけて ある。体内プールの大きな物質に対して除去効率の悪い 点や代謝調節機能を有さない点などがあり，臨床的には いまだ満足すべきものではない。

肝茼の多くの代謝調節機能を完全に代行させるために は，生体材料そのものを利用するのが最も確実な力法で ある。生体材料を用いた肝臟補助装置の開発としては， これまでにも肝スライス ${ }^{3 !}$ ，遊離肝勫胞"，摘出肝 ${ }^{5)}$ ， 肝組織片6)などを用いた方法が追求されてきたが、それ らの機能性や長期保持性，さらには装置への組み込みな ど解決すべき問題点を抱えたままの状態にあり，臨床応 用への有望なアプローチとは見なされていない。

最近では，奉用性の高い人工肝臓を確立するために は，肝機能の主役を担う肝細胞に任せる以外に方法はな いという考えが強まってきた。こうして肝細胞を人工基 質材料上に固定したハイブリッド型人工肝荿が，重症肝 疾患の治療法のひとつとして本命視されるに至ったので ある。この方法は正常な機能を有する肝細胞を单離し， 生体内に極めて近い状態を与えることのできる人工基質 材料(細胞接着用マトリックス)上で初代培養し大半の肝 機能を長期維持，さらにその機能発現を人為的に制御し
てハイブリッド化しようとする試みである。

\section{3. 初代肝細胞培養の進歩}

肝機能の中心を担う肝細胞を応用したハイブリッド型 人工肝䐵を開発するためには，まず肝細胞を単蜼し，in vivo 同様の機能発現性と長期生存性を有する培養シス テムを開発することが必要である。肝細胞培養の発展




流法などにより，肝組織から機能を維持した実質細胞の みを効率よく単離することが可能となったことに端を発 している。この単離法の開発により初代肝細胞の単層培 養を用いた肝機能の生化学的研究が活発に行なわれるよ うになり，また，近年その技術が著しく進歩しだす。 しかしながら，肝組織からひとたび取り出された肝細胞 の機能発現性や生存性は，生体内でのレベルに比較する と際だって低下している。それ故, 生体内により近いレ ベルで機能発現させるたかの培養システムの開発を目的 に，基質材料の調慗をはじめ ${ }^{11-13) ， ホ ル モ ン ~}{ }^{14,15)}$ ，薬 剂 ${ }^{16.17)}$ などの添加因子に関する研究，さらに酸素の添 加方法, 無血清初代培養 ${ }^{18)}$ など様々な研究が行なわれ てきた。そして単嚾された肝細胞の多くの機能を相当程 度維持することが可能になってきた。これらの詳細につ いては，総説 ${ }^{19,20)}$ を参照されたい。

これまで報告されてきた肝細胞培養システムは, 生体 内の細胞形驡とは大きく異なる伸展形態の単層培養が主 体である。”数日間以内の検討では生体を反映した優れた モデルであるが，長期生存性や機能維持性，さらには增 殖などの面においてまだまだ多くの解決すべき問題点を 残している。この肝細胞培盖システムをハイブリッド型 人工肝臓に応用するためには，肝細胞を安定に固定でき る基質材料の開発に加之，大量の肝細胞を確保するため の堌殖性の六進・凍結保存・小容積の中に十分な肝細胞 を生存させる高密度培羔システムの確立など解決ずき 重要な課題か残されている゙1)。

\section{4. ハイブリッド型人工肝䁃に向けての 基暂材料の設計}

䀒細胞注接着依存性を有する細胞であるため，生体外 での浮遊状態においてその生存性を長期間維持させるこ とは困難である。肝細胞培美用基質材料としては，一般 に生体由来のコラーゲンやフィブロネクチンなどの接着 性タンパク質が用いられてきた。しかし，近年筆者らに よって全く異なった観点から，肝細胞の有する高度なオ リゴ精鎖の識別機能に着目し、アシアロ糖タンパク質の モデル材料として肝細胞特異的な人工基質材料(PVLA 
: poly-N-p-vinylbenzyl-D-lactonamide) が 設計され $た^{22)}$ 。

血液中に存在する糖タンパク質が老朽化すると糖鎖末 端加らシアル酸基を失い，次の末端となるガラクトース 残基を露出する。これがアシアロ糖タンパク質であり， 肝細胞によって特異的に処理される。肝細胞はこの末端 ガラクトース残基周辺を明確に認識し、アシアロ糖タン バク質を細胞内に取り迄んで分解する。このガラクトー ス残基の認識と細胞内取り込みに関与するのが肝細胞膜 表面に存在するアシアロ糖タンパタ質レセプターであ る。この細胞内取り込みに関与するレセプターを上手く 利用することで，肝細胞を安定に固定する材料として設 䚵されたのがPVLAである(図1参照)。


アシアロ糖タンパク質モデル
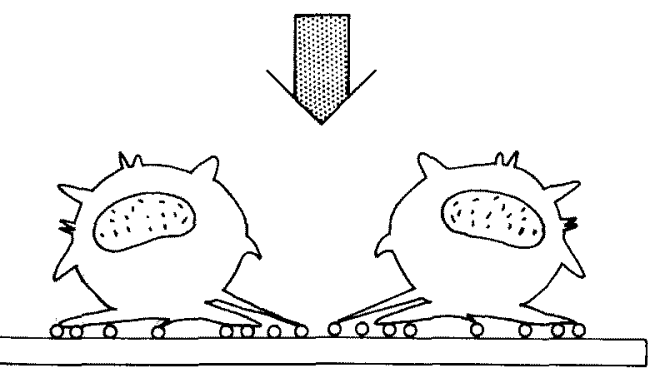

PVLA 上に接着した肝緗胞

図1アシアロ糖タンパク質モデルとして合成された PVLAの構造単位と肝紐胞との相互作用


図 2 各種基質上で無血清培䖯された肝細胞の機能保 持。(A)培盖日数とアルブミン合成能の関係。(B)培盖 日数と胆汁酸合成能の関係

人工基質材料である PVLAにおける肝細胞の初期接 着率は，天然基質材料であるコラーゲンやフィブロネク チン上でのものと同等に非常に良好な結果を示した。ま た，興味哚い現象としてコラーゲンやフィブロネクチン 上に接着した訮細胞は，接着後 2 時間あたりから伸展 (spreading)を開始するのに対し，PVLA 上では後述す るようにコーティング濃度を希薄したり，細胞增殖因子 を添加しない限り数日閒経過した後も伸展形態を示すこ となく，単離時の形態に近い球状形態(round shape)を 保持したまま接着・生存してゆく。また，图 2 に示すよ うにアルプミン合成分泌能や胆汁酸形成能などの膰異 的な機能についてもコラーゲンやフィブロネクチン上で の培養肝細胞に勝るとも少らない良好な維持を示した。 PVLA 上の肝細胞が伸展することなく球状形態を保持し たまま，肝特異的機能を良好に保持することは人工基質 材料 PVLAならではの特性であろう(表 1 参照)。

\section{5. 培養肝細胞の分化・增殖の制御}

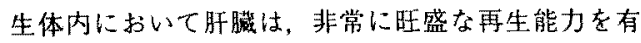
し，例えば成熟ラットの肝䑏の約70\%を部分切除して も，ほほ10日で元の大きさまで回復する。しかし，生体 外に取り出された肝細胞の生存性は，通常の培莀条件下 においてほほ1週間が限度であり，そのころから肝細胞 は基質上から剥離して死隇してゆく。それ故, 生体外に おいて高い機能発現性や長期生存性を得るためには，培 
表 1 天然基質と人工基翼上に扝ける肝細胞の細胞挙動の比較

\begin{tabular}{|c|c|c|c|}
\hline 基 算 材 料 & コラーゲン & フィプロネクチン & PVLA \\
\hline 諗識・結合サイト & インデリリンャミリー & インデグリンファミリー & $\begin{array}{l}\text { アシアロ糖タンバク㬴 } \\
\text { レセブター }\end{array}$ \\
\hline 初期接着性 & $+t$ & ++ & ++ \\
\hline 接着に及ぼす二伍カチオンの効果 & $\mathrm{Ca}^{2+}<\mathrm{Mg}^{2+}$ & $\mathrm{Ca}^{2+}=\mathrm{Mg}^{2+}$ & $\mathrm{Ca}^{2+}$ \\
\hline 低温度 $\left(4^{\circ} \mathrm{C}\right)$ 下に扔ける接着性 & - & & ++ \\
\hline 熱処理した基質への接着性 & + & + & $+t$ \\
\hline 長期生存性 & ++ & ++ & ++ \\
\hline 伸展活性 & ++ & ++ & - \\
\hline 特異的機能発現性 & ++ & ++ & +++ \\
\hline DNA 合成能 & ++ & ++ & - \\
\hline
\end{tabular}

養肝細胞の分化と增殖を制御することが必要になってく る。また，ハイブリッド型人工肝蔵の開発には多量の培 養肝細胞を必要とすることから，增殖を絽り返す長期継 代培萣を可能にすることも重要な課題となる。

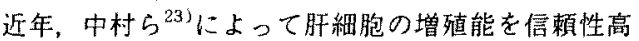
く測定できる方法が開発され，生体外に扔いて分化機能 発現性と增殖との調節機構が明らかにされた。培養肝緗 胞の増殖は低細胞密度で促進され，逆に分化機能は增殖 と相反して高細胞密度においてその発現が促進され

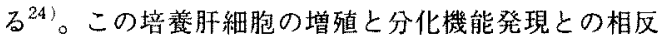
的な細胞密度依存性調節は，肝細胞膜表面に存在する因 子(CSM : cell surface modulator)によるものと考えられ ている ${ }^{25)_{0}}$

また，筆者らは前述した人工基質材料 PVLAのコー ティング濃度を変化させることで，培養肝細胞の増殖能 と分化機能発現性との間にPVLA コーティング濃度依 存的な相反的関係のあることを明らかにした26)。つま り，PVLAのコーティング濃度を低くすると接着した肝 䋖胞は伸展形態を示し，DNA 合成能の指標である $\left[{ }^{3} \mathrm{H}\right]$ チミジンの取り込みがえ進し，逆にコーディング濃度を 离めると接着形態は球状化し，その変化にともない $\left[{ }^{3} \mathrm{H}\right]$ ーチミジンの取り込みが顕著に㧕制された。一方， 分化機能の代表である胆汁酸形成分泌能は，PVLAのコ ーティング濃度を亮かると $\left[{ }^{3} \mathrm{H}\right]$-チミジンの取り达みに 相反して上昇する傾向を示し，逆にコーティング濃度を 低くするとその発現性は低下する傾向を示した。PVLA はコーティングする際の溶液濃度によって培篒シャーレ 表䣫への吸着状態がミセル状態加らアンホールディング 状態まで形成し得ると考えられている27?。すなわち肝 細胞が PVLAの堷養シャーレ表面人の吸着状態の微妙 な差を(アンホールディングからミセル状態)を明確に認
識した上での細胞応答の差異と考えられる(図 3 参照)。 このように基質材料の設計サイドから培鉒肝細胞の分 化・增殖を相当程度制御することが可能になった。

生体内レベルにより近い機能発現性を有する継代培旁 法の確立は，ハイブリッド型人工肝葴の開発にとって必

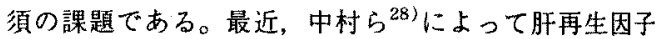
の本体と考之られる肝細胞增殖因子(HGF： hepatocyte growth factor)が発見され，HGF 遺伝子のクローニン グ,さらには全１次構造の解析がなされた，HGFは肝 練胞に特異的に作用し，わずかの濃度 $(\mathrm{lng} / \mathrm{ml})$ において も初代培養肝細胞の DNA 合成を顕著に促進し，増殖を 引き起こす。さらに，HGFは培養肝細胞を用いた実験 において強い抗肝炎作用を有することも明らかにされ た。この HGF の発見によって，肝再生機構の解析をは じめとし，肝細胞の継代培盖法の確立，さらにはハイフ リッド型人工肝胧の開発に至るまで肝臟に関する研究に 大きな㵋献をするものと思われる。

\section{6. 肝細胞高密度培荃システムの確立}

肝組織内において，肝細胞は互いに接触し三次元的細 胞社会を形成している。そして，細胞どうしは互いに細 胞間マトリックス(extra-cellular matrix)成分を介して 相互作用を行なっている。これらのことから，肝細胞の

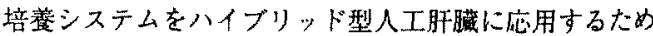
には，生体肝組織に近いレベルでの高密度培養システム を確立する必要がある。現在，高密度培盖システムとし て動物実験で試行されているものとしては，マイクロビ 一无型，重層基型型，浮上型球状凝集塊(spheroid), 自 己組織再構築による多層集合体などが挙げられる。

マイクロビーズ型としては，肝細胞をアルギン酸カル シウムを用いて包括固定型ビーズとして培養するシステ 




图 3 人工基質材料(PVLA)の吸着制御による肝細胞の伸展と增殖・分化の制御

ムが報告されている タンパク質合成活性やホルモン応答性, さらにはアンモ ニアをはじめとした肝性昏睡を引き起こすような物質の 解毒など，それらの機能を良好に7日間維持したとされ ている。また，重層基盤型肝モジュールは，コラーゲン をコーティングしたガラス平板に初代培養した肝細胞を 固定し，多篔に重ねたもので，培苓実験では 2 週間，肝 贜を摘出した犬を用いての灌流実験では65時間生存させ たとの報告がなされている30)。Spheroid 形成による培 盖法は，グリコサミノグリカンやプロテオグリカンを基 質材料として行なわれ，単層培養と比較すると機能維持 および形態維持が良好であり無血清培盖下においても1 ケ月以上の生存性が確誌されている31.32)。また, 最近 肝組織から抽出したプロテオダリカン上あるいは少量の アミノ基の導入されたポリスチレンシャーレ上での無血 清培善条件下において spheroidを形成した培養肝細胞 は, 細胞增殖能を顕著に抑制し, 分化機能のひとつであ るアルブミン合成分泌能を14日間にわたり良好に維持し たと報告されている33)。この spheroid 培盖法は, 八イ ブリッド型人工肝臓の開発のみならずバイオリアクター
としての期待も持たれている。

一方，筆者らは先に述べた人工基質材料 PVLA 上に おいて EGF(上皮細胞增殖因子 Epidermal growth factor)やインスリンなどの細胞增殖因子の刺激によ り，球状形態で接着した個々の細胞が PVLA 上を移動 した後，長期生存性と高機能発現性を有する基質接着型 の多層集合体を形成することを見い出しだ4) (図 4 参 照)。この多層集合体は, EGFやインスリンの添加浱度 に依存し，さらに両ホルモンの共存下において相加的効 果を示した。多層集合体を形成した培盖肝細胞は, 単層 な培盖系に比ベアルブミ合成分泌能を良好に維持し，25 日目までの生存か確認されている。このことから肝細胞 の多層集合体は，機能発現的にもより生体内に近い安定 な環境を得たものと考えられる(図 5 参照)。興味あるこ とに，図6に示すように細胞增殖因子である EGFやイ ンスリンの存在にもかかわらず，多層集合体を形成した 培養肝細胞は，コラーゲンやフィブロネクチン上での単 層培養系に比べ DNA 合成ひいては細胞增殖の指標であ る $\left({ }^{3} \mathrm{H}\right)$ チミジンの取り込みを顕著に抑制した。この多 層集合体においても細胞間の接触がより密になるため細 

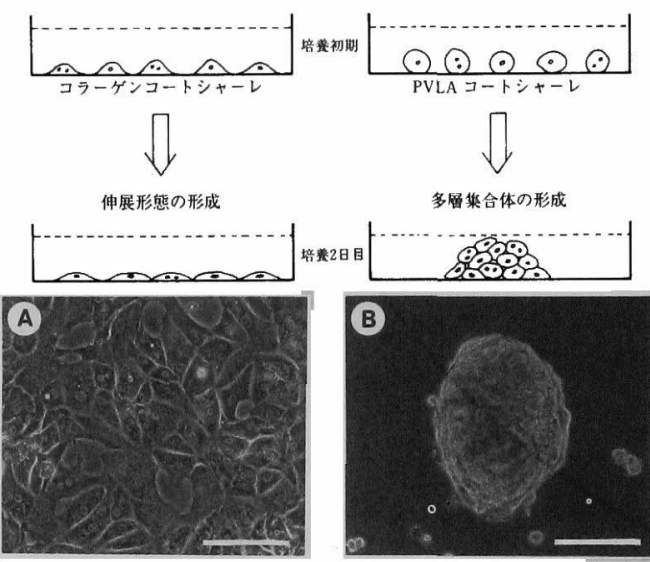

図4 肝細胞のコラーゲン上での単層培養と PVLA 上 での多層培養(多層集合体)

写真はコラーゲン (A) と PVLA (B) 上で 2 日間培養後に 位走査顕微鏡にて撮影(スケールバー：100 $\mu \mathrm{m}$ )
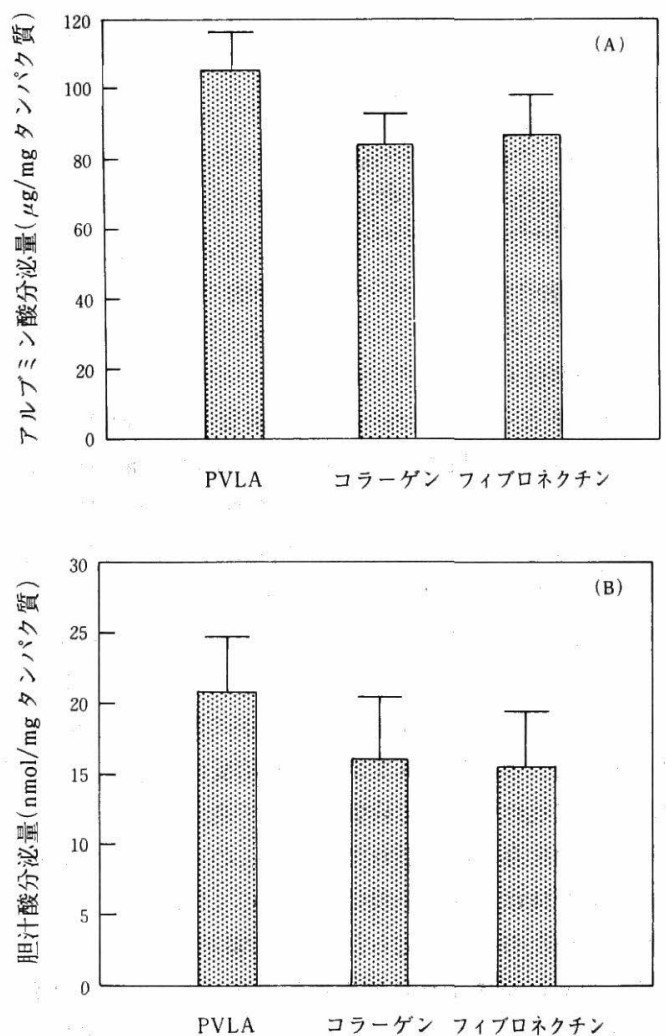

図 5 PVLA 上で多層集合体を形成した培養肝細胞とコ ラーゲンおよびフィブロネクチン上で伸展した培養肝細 胞とにおけるアルブミン合成能 $(\mathrm{A})$ と胆汁酸形成能(B) ( 2 日間培養での評価)

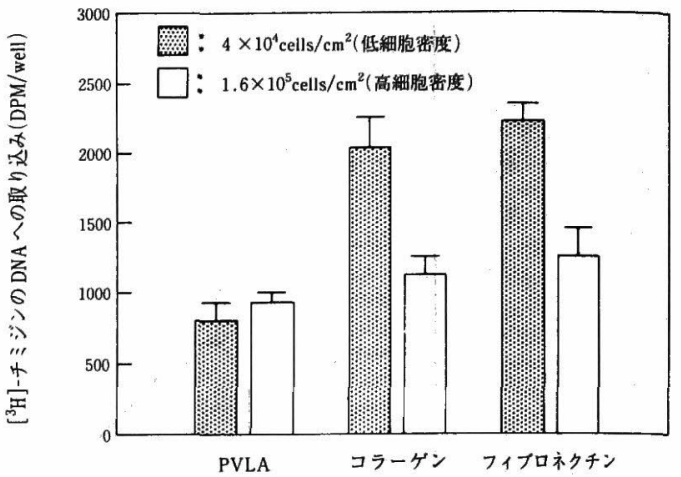

図6 各種基質上での培養肝細胞の $\left[{ }^{3} \mathrm{H}\right]$-チミジン取り 込みによる DNA 合成能の評価

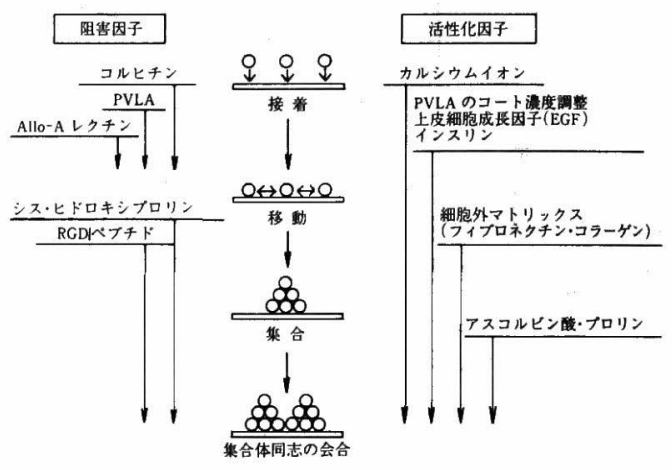

図 7 PVLA 上での培養肝細胞の多層集合体形成過程に おける活性化因子と阻害因子

胞間接触を介して増殖と分化が制御されている可能性が 考えられる。筆者らの系統的な研究によりここ多層集 合体の形成は, PVLA を明確に認識した上でアシアロ糖 タンパク質レセプターと PVLA との相互作用に基づい た細胞移動を行なった後，自己産出した細胞外マトリ\% クス成分を用いて組織再構築が行なわれることが明かに されている ${ }^{35)}$ (図 7 参照)。この人工基質材料 PVLA 上 での新たな肝組織様多層集合体(三次元培養系)は, 現在 期待されつつあるハイブリッド型人工肝臓の開発や肝組 織の再構築化機構の解析などにとって, 非常に安定で感 度の高いモデル系を提供するものと考えられる。

\section{7. 肝細胞と肝類洞壁細胞との混合培養}

肝臓は, 肝実質細胞(肝細胞)のみによって構成されて いるわけではなく, 類洞内皮細胞, Kupffer 細胞, Ito 細 胞, pit 細胞, 胆管上皮細胞, 結合織細胞 (線維芽細胞) など数種の細胞群によって構成されている。それ故, 肝 細胞培養システムをモジュールに組み込んだハイブリッ ド型人工肝蔵を開発するためには，生体内での組織と同 

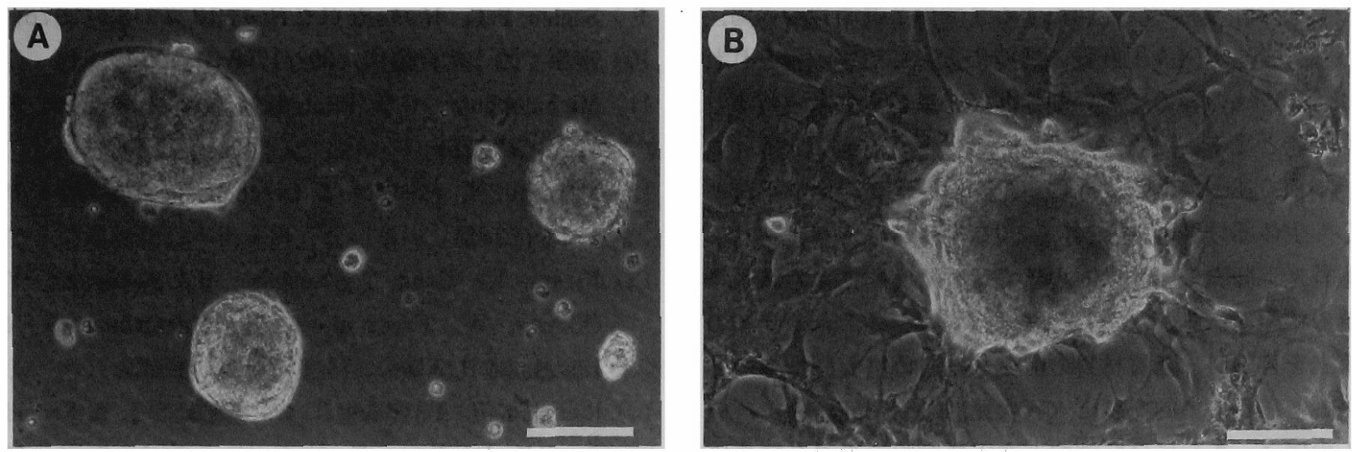

図 8 PVLA 上での肝細胞多層集合体 $(\mathrm{A})$ と非実質細胞との混合培盖 $(\mathrm{B})$ 。培養 6 日目に位走查顕微鏡にて撮影 (スケールバー : $100 \mu \mathrm{m}$ )

様にこれら細胞群による共同作用に基づく肝組織様培養 システムが有効であると考えられる。

近年, 肝組織細胞群を個々に分離し, in vitro で培養

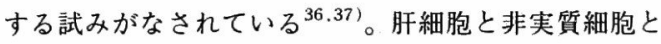
の混合培養において，增殖因子を全く含まない条件下で も肝細胞は DNA 合成を開始することが報告され，非寒 質紏胞の産出するなんらかの物質によるものと考えられ

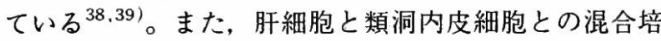
養条件下において肝細胞のアルブミン合成分竧能が，肝 細胞のみの培養でのものと比較し, 有意に発現され長期 間にわたり維持されると報告されている(0)。このよう に混合培養システムは肝細胞の機能発現性や肝組織再構 築に及ほす影響などの解析には有用である。しかし，単 層培養下に掞ける肝細胞と非実質細胞との混合培養にお いて, 肝細胞と非実質細胞は個々に島状の単層を形成し 直接の cell-cell contact を形成しない。そこで八イブリ ッド型人工肝臓の開発に向けては, 三次元培養下での混 合培養システムの確立に期待がもたれるのである。

肝組織由来のプロテオグリカン上での spheroid 形成 過程に類洞内皮細胞を添加し混合培養を続けると, 肝細 胞のみの場合と同様に spheroid が形成される ${ }^{11}$ 。この 混合培養した spheroid 表面の形態钼察においては, 類 洞内皮細胞と思われる極めて薄い一層の細胞によって覆 われており，肝細胞との間には肝組織を反映したDisse 腔様細胞間隙か観察された ${ }^{12}$ 。この類洞内皮細胞によ って覆われた spheroidにおいて，機能維持性や形態的 安定性が示されれば肝バイオリアクターとして利用する 有効な方法になり得るものと考えられる。

一方，筆者らは先に述べた人工基質材料 PVLA 上で の多層集合体培養システムにおいて, 肝細胞と非実質細 胞との混合培養を試み，興味ある現象を見い出した。肝 細胞の多層集合体の形成には，先に述べたように EGF
やインスリンなどの細胞增殖因子の存在が必要である が，これら增殖因子の全く存在しない混合培養系におい て, 肝紐胞は顕著な多層集合体を形成し, 增殖因子の添 加によって形成した多層集合体と比較して良好な長期生 存性と機能発現性を示すことが明らかとなった(図 8 参 照)。PVLA は, 肝細胞と異なり非寒質細胞には接着性 を発揮しない材料であるが，培養開始後ほほ 4 日目に は、多層集合体の周囲に伸展した非実質細胞群が観察さ れた。また，電顕的観察において集合体の一部の表面に は内皮細胞が覆い,さらに Kupffer 細胞が接着する形態 も観察された。コラーゲン上での混合培盖では、ほほ 10 日前後で線維芽細胞様の細胞群が基質面を埋めつくし, 肝細胞を剝離してしまったが，PVLA 上での培養におい ては，多層集合体の周囲のみに非実質細胞群が伸展接着 し,この現象は 1 ケ月以上にわたり維持された。この PVLA 上での非実質細胞の接着と生存に関する詳細は, 現在検討中であるが，細胞自らが産出する細胞外マトリ ックス成分によるものであろうと考えられる。いずれに せよPVLA 上での混合培養系は，肝細胞と非実質細胞 との相互作用の解析やハイブリッド型人工肝臓の開発に むけての肝組織様システムとして期待されるモデルであ ろう。

\section{8. おわりに}

肝組織がなんらかの原因により障害を受けると，肝特 異的代謝調節の急激な低下により死に至る場合も多い。 特に, 劇症肝炎による急性肝不全の場合には肝性昏睡に 陥り，ほとんどの患者が短期間の内に死亡してしまう。 わが国の急性肝不全死亡者は，年間約 1 万人，このうち 3,000から4,000人の死亡者が劇症肝炎によるものと報告 されている。しかし，劇症肝炎に陥った患者ですら，な お多くの残余肝細胞数を残している場合がある。したが 
って残余肝細胞が機能回復するまでの 2 週間程度の間， ハイブリッド型人工肝䐵の補助によって治療が施されれ ば，死亡率の極めて高い暒症肝炎の患者を救命すること も可能となる。

本稿で述べさきなうに，重篤な肝疾患の治療手段と して生体部分肝移植と共に，現在期待されるハイブリッ ド型人工肝臓の開発は，現状では動物実験による試行錯 誤の状態である。しかし，肝細胞培盖システムの究極の 確立を目的に，基啠材料の開発をはじめ培養肝練胞の分 化・增殖の人為的な制御，三次元的な高密度培盖シ入テ ムの確立，さらには肝細胞と非赛翼細胞との混合培に よる肝組織梯培养システムの開発など㥞々な面から活発 な研究が遂行されている。战らく困難とされてきた成熟 肝細胞の生体外での增殖にも成功し，肝緗胞の增殖促進 因子の本体すら明らかにされてきた。生体部分肝移植手 術に代わりハイブリッド型人工肝炡を用いた肝疾患の治 㙩法の出現も近い将来必ずや可能になることが期待でき よう。

\section{竧辞}

本研究の遂行にあたり細胞增殖能の評価検討において 御指導，御協力を賜った北里大学看護学部山本 昇教授 に心より謝意を表します。また，本稿の執筆にあたり研 究を共にした当研究室の武井由香，小林 明，後藤光昭 の各研究貝の多大なご協力に心より感謝致します。

\section{荟考文献}

1) Kiley, J. E., Welch, H. F., Pender, J. C. \& Welch, C. S. Proc. Sac. Ep. Biol. Med., 91, 489-490 (1956)

2) Yatzidis, H.: Proc. Eur. Dical Transplant Assoc., 1, 83. (1964)

3 ) Soyer, T. Lempinen, M. \& Eiseman, B.: Ann. Surg., 177, 393-401 (1973)

4) Olumide, F., Eliashiv, A., Kralios, N., Norton, L., \& Eiseman, B.: Surgery., 82, 599-606 (1977)

5 ) Gundermann. K. J. \& Lie. T. S.: Artificial Organs, 4. $27-29(1980)$

6) Kawamura, A., Takahashi, T., Kusumoto, K., Kyuuno, K., Kumagai, F., Kushida, T., Saji, H., Matsusita, M. Meguro, J., Tsuburaya, T., Kakita, A., Nakanisi, Y., Kuraoka, Y. \& Sakao, N.: Jpn. J. Artif. Organs, 14. 253-257 (1985)

7) Howard, R. G. \& Pesch, L. A.: J. Biol. ('hem., 243 , 3105-3109 (1968)

8 ) Berry, M. N. \& Friend, D. S.: J. Cell Biol., 13, $506-520(1969)$
9 ) Seglen. P. O.: Methods Cell Biot., 13, 29-83 (1976)

10）市原 眧：総合䠦床，39，1798-1800（1990）

11) Michalopoulos, G \& Pitot, H. C.: Exp. Cell Res., 94. $70-78(1975)$

12) Marceau, N., Noel, M. \& Deschenes, J.: In Vitro, 18, 1-11 (1982)

13) Hirata, K., Usui, T., Koshiba, H., Maruyama, Y., Oikawa, W., Freeman, A. E., Shiramatsu, K. \& Hayasaka, H.: Cann., 74, 687-692 (1983)

14) Richman, R. A., Claus, T. H., Pilkis, S. J. \& Friendman, D. L.: Proc. Natl. Acad. Sci., U. S. A., 73. 3589-3593 (1976)

15) Tanaka, K.. Sato, M., Tomita, Y. \& Ichihara, A.: J. Biochem., 84, 937-946 (1978)

16) Miyazaki, M., Handa, Y., Oda, M. Yabe, T. \& Miyano, K.: Exp. Cell Res, 159. 176-190 (1985)

17）戸辺成四郎，武井由香，小林一清，赤池敏去：応用 細胞生物学研究，8，48-56 (1990)

18) Nakamura, T., Asami, O,, Tanaka, K. \& Ichihara, A: Exp. Cell Res., 155, 81-91 (1984)

19) Guillouzo, A. \& Guguen-Guillouzo, C. (eds.): "Isolated and Cultured Hepatocytes.", John Libbek Eurotexw. London \& Paris, (1986)

20）中村敏一：“初代培着肝細胞実験法”，学会出版セン 夕- (1987)

21）赤池敏宏，户辺成四郎：細胞工学，8，219-226 (1989)

22）赤池敏宏，小林 明，戸辺成四郎，真栄田篤：人工 溚器, $17,227-230$ (1988)

23) Nakamura, T., Tomita, Y., and Ichihara, A.: J. Biochem. 94, 1029-1035 (1983)

24) Nakamura, T., Yoshimoto. K., Nakayama. Y., Tomita, Y. and Ichihara, A.: Proc. Nall. Acad. Sci. U. S. A., 80, 7229-7233 (1983)

25) Nakamura, T., Nakayama, Y. and Ichihara, A.: J. Biol. Chem., 259. 8056-8058 (1984)

26）小林 明，武井由香，巨辺成四郎，後藤光昭，関根 卓志，增本安紀，山本 昇，小林一清，赤池敏宏： 高分子学会予稿集，39，2580-2583（1990）

27）高监，小崇，一棈，松田武久，赤池钽宏：生体材 料, 8, 122-128(1990)

28）中村敏一：开イエンス，20(3)，6-17(1990)

29) Miura, Y., Akimoto, T., Fuke, Y., Yamazaki, S. and Yagi, K.: Artif. Organs, 11, 361-365 (1987)

30）熊谷文昭，円谷敏彦，中島保明，長谷秦司，船津昭 彦，橋村悦郎，駒井 喬，今 忠正，中村敏一：人 
工䐵器, $17,175-178(1988)$

31) Landry, J., Bernier, D.. Ouellet, R., et al: J. Cell Bio., 101, $914-923$ (1985)

32) Fujita, M, Spray, D. C., Choi, H, et al: Hepatologr, 7, 1S-9S (1987)

33）高香弘行，小出典男，坂口热作，川口光浐，武南達 郎，小野良策，松島 筧。辻孝夫：人工臟器， 19, $1165-1168$ (1990)

34）戸辺成四郎，武井由香，真栄由篤，赤池敏宏，小林 一清：人工烚器, 19, 1156-1160 (1990)

35） 万辺成四郎，武井由香，久々宫岳志，小林 明，小 林一清, 赤池敏宏：人工臟器 (印刷中)

36) Doolittle, R. T.. \& Richter. G. W..: Labo Incest. 45 $558-566(1981)$

37) 向坂彰太郎，野口和典，河原酷彦、椎藤和久，赤司
隆裕，石井良知，上野隆登，吉武正男，阿部弘彦， 谷川久一：肝臓，27，487-495（1986）

38) Shimaoka. S., Nakamura, T. \& Ichihara, A.: Exp. Cell Res., 172, 228-242(1987)

39) Yamamoto, N., Imazato, K. \& Masumoto, A.: Cell Struc. Funct., 14, 217-229 (1989)

40) Guillouzo, A. \& Guguen-Guillouzo, C., (eds.): "Isolated Cultured Hepatocytes", John Libbey Eurotext London \& Paris. pp. 155-170 (1986)

41）荒木康之：捯山医学会雑誌，100，371-376（1988）

42) Asano, K., Koide, N., Kawaguti, M., Takenami, T. Matsushima, M., Mori, M. \& Tsuji, T. J. Clin, Electronmicrescopy: 21, 5-6(1988)

(平成 3 年 1 月 18 日受理)

\section{シンポジウム「絹蛋白質の生産」}

主 催：日本学術会議虫系学会研究連絡委員会

共 崔: 䄉維学会ほ㐰

日 時: 平成 3 年 4 月 5 日(金) $13: 00$ - $16: 30$

会 埸: 日本学術会議講堂 (1階)

干106 東京都港区六本木 7-22-34（䨮話 03-3403-6291）

(地下鉄千代田線「乃木坂駅下車)

\section{プログラム：}

開会挨㨃

(1) 絹采腺細胞の欋造と機能

(2) 恽蛋白質遭伝子の発現上組み換元

(3)ウイルスベク夕一を利用した有用蛋白質の生産 閉会挨摱
日本学術会議第 6 部 間 和夫

東䍗大客員 赤井弘 㖘水省省系・鼠虫研 田村 倰樹 第一慗薬(株)，传伯 欣之 信州大・䋐維 嶋崎 昭典 